\title{
Lockdown Responses to COVID-19
}

Violeta A. Gutkowski

This article describes the relationship between countries' lockdown responses to the COVID-19 pandemic and those countries' political rights and civil liberties, macroeconomic variables, and vulnerability to the virus. Political rights and civil liberties cannot explain the differences in lockdown timing across countries. Countries with high contagion exposure due to weak water sanitation and weak health systems locked down their economies as fast as possible to reduce contagion. However, countries more vulnerable to COVID-19 due to large fractions of elderly and smokers in the population did not respond differently from less-vulnerable countries. Interestingly, macroeconomic variables that did affect the timing of lockdowns were the sizes of a country's financial and trading sectors, even when differences in income and population density are taken into account. (JEL C10, H4, I18)

Federal Reserve Bank of St. Louis Review, Second Quarter 2021, 103(2), pp. 127-51. https://doi.org/10.20955/r.103.127-51

\section{INTRODUCTION}

Why did some countries lock down their economies faster than others? Was lockdown speed related to a country's economic condition, democratic rights and civil liberties, or vulnerability to contagion and death? This article aims at understanding differences across countries in response to the COVID-19 pandemic, focusing on lockdown speed.

Figure 1A shows that there is dispersion in countries' responses to COVID-19. After having 100 confirmed cases, some countries remained fully open, while others had closed their economy even before reaching this point. In addition, while many countries locked down their economy after having a "sufficient" number of confirmed cases, as shown in Figure 1B, what each country considered sufficient seems to vary. For many countries 100 cases was enough, while for others 2,000 cases was not enough to restrict activity.

Recently, a wide literature combining economic models with the SIR model of contagion, used by public health specialists, has highlighted the trade-off between reducing economic activity by reducing social interaction at businesses and reducing the rate of infections. At

Violeta A. Gutkowski is a lead analyst at the Institute for Economic Equity at the Federal Reserve Bank of St. Louis.

(c) 2021, Federal Reserve Bank of St. Louis. The views expressed in this article are those of the author(s) and do not necessarily reflect the views of the Federal Reserve System, the Board of Governors, or the regional Federal Reserve Banks. Articles may be reprinted, reproduced, published, distributed, displayed, and transmitted in their entirety if copyright notice, author name(s), and full citation are included. Abstracts, synopses, and other derivative works may be made only with prior written permission of the Federal Reserve Bank of St. Louis. 


\section{Gutkowski}

\section{Figure 1}

\section{Country Containment Responses to COVID-19}

\section{A. Dispersion in responses to COVID-19}

Number of countries

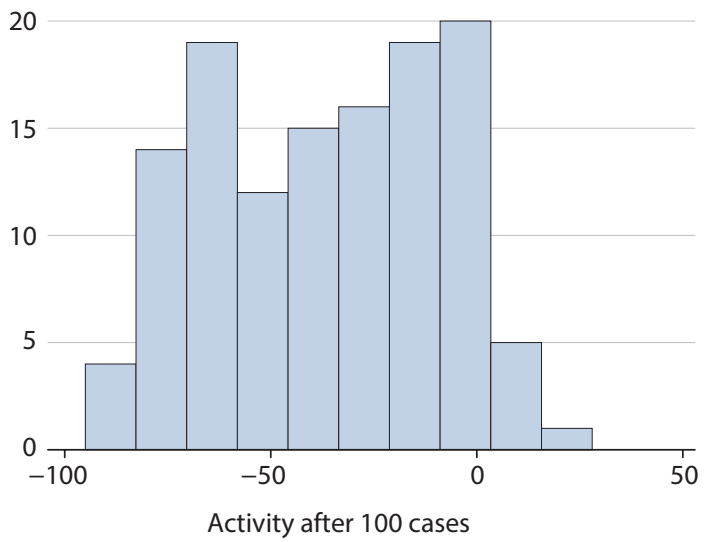

\section{B. Confirmed cases before lockdown}

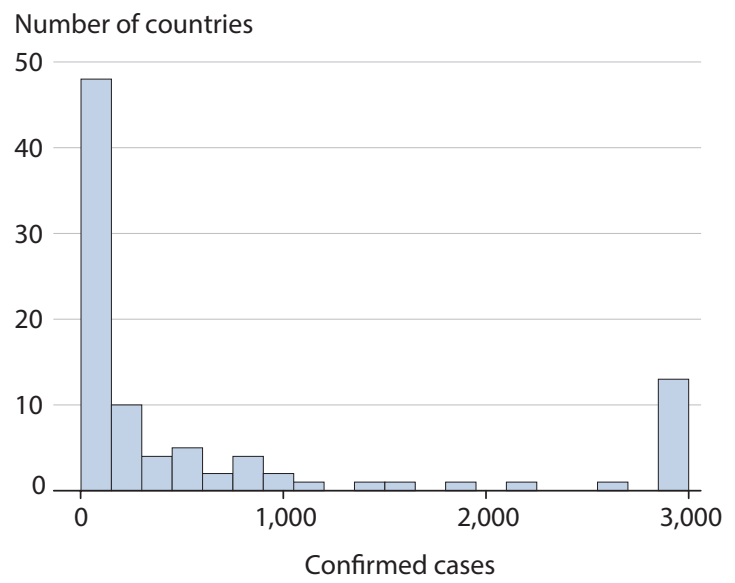

NOTE: The lockdown measure in Panel B accounts for a country's economic activity falling at least 65 percent relative to the baseline. Note that while retail and recreation activity is positively correlated with economic activity, a 65 percent fall in that activity does not imply a fall in overall economic activity of the same degree.

SOURCE: Retail and recreation activity constructed using Google's (2020) "COVID-19 Community Mobility Reports."

the heart of the standard SIR model, there is a matching function that mixes susceptible individuals (S) with infected individuals (I). ${ }^{1}$ Because private and public returns to social distancing differ due to externalities not taken into account by private agents, intervention could be desirable. Farboodi, Jarosch, and Shimer (2020) show that optimal policy reduces social interaction immediately relative to laissez-fare where individuals only reduce activity once the risk of infection becomes nonnegligible. Optimal social distancing starts as soon as the disease emerges, immediately imposing social distancing, for example, through stay-at-home orders. This sudden drop in activity delays the spread of infection and hence "buys time." That is, prior to development of a cure, social distancing enormously reduces expected fatalities and yields a substantial welfare gain, albeit at the cost of a reduction in social and economic activity.

The first and main hypothesis of this study is that lockdown timing and intensity in response to the pandemic can be explained by country differences in political rights and civil liberties. The lack of political rights and civil liberties can improve the externality problem. In other words, less individual liberty might imply more coordination and compliance, making the solution to the problem closer to the social optimum.

On one hand, on January 23, 2020, with a population of more than 11 million and less than 500 confirmed cases, Wuhan, China, was the first city to lock down; several other cities in the province of Hubei, China, followed immediately. On the other hand, on March 19, with a population of 36 million and already more than 1,000 confirmed cases, California was the first U.S. state to issue a statewide stay-at-home order. $\stackrel{2}{ }$ China and the Unites States have very 
different degrees of civil liberties, and stay-at-home orders have been of different intensities and at different points in time. For example, while many cities in China faced a full quarantine where people were not allowed to leave their homes, this did not happen at any point in the United States.

Disparity in the responses of the United States and China to COVID-19 could be driven by the differences in the countries' individual liberties. How did countries between these two extremes respond to COVID-19? I would expect to see that countries with high levels of freedom, political rights, and civil liberties would take significantly longer to force their population to quarantine and issue lockdowns. However, I do not find evidence to support the idea that countries with lower levels of freedom responded faster to the pandemic through lockdowns.

This finding is consistent with Frey, Chen, and Presidente (2020). Using the Oxford COVID-19 Government Response Tracker (OxCGRT), they test the belief that autocratic governments have been more effective in reducing the movement of people to curb the spread of COVID-19. They find that autocratic regimes imposed more-stringent lockdowns and relied more on contact tracing. However, they find no evidence that autocratic governments were more effective in reducing travel and find evidence to the contrary: Countries with democratically accountable governments introduced less-stringent lockdowns but were approximately 20 percent more effective in reducing mobility than their less-democratic counterparts who enforced the same level of policy stringency. Cronert (2020) investigates the institutional determinants of the timing of COVID-19-related school closures around the world, focusing on the role of democracy and administrative state capacity. That study finds that other things being equal, democratic countries tended to implement school closures quicker than those with a more authoritarian regime, while countries with high government effectiveness tended to take longer to implement school closures than those with less-effective state apparatuses. Similarly, Bosancianu et al. (2020) find that, to date, political and social variables such as populist governments, right-leaning governments, or women-led governments have little explanatory power over and above simple demographic and health indicators.

Second, I study whether differences in health systems and sanitation services as well as fatal vulnerability to the virus can explain the variation in country responses. The health status of the population measures the set of individuals potentially susceptible to the virus. In the SIR model, infected people transmit the virus to susceptible people at a rate that depends on the nature of the virus and on the frequency of social interactions. Populations with potentially better health might not get infected as easily from contact with individuals with the disease or if infected might have a lower likelihood of death. Additionally, populations with better sanitation services might also have a reduced likelihood of contagion. Similarly, hospital capacity could affect the payoff function of the policymaker. For example, some models assume that there is a capacity constraint in the health care system and that part of the reason to lock down is to avoid exceeding hospital capacity (Jones, Philippon, and Venkateswaran, 2020). One would expect that countries that are more vulnerable to contagion, have a weak health system to fight the virus, or have a large fraction of the population with pre-existing characteristics that increase the likelihood of death would respond faster to the pandemic. I find that countries that were highly exposed to fast COVID-19 contagion had a much faster response than coun- 


\section{Gutkowski}

tries that had better access to safe drinking water and sanitation. However, countries more vulnerable to COVID-19 due to a large fraction of elderly or smokers in the population do not seem to have responded faster than less-vulnerable countries. Nevertheless, after controlling for differences in income, none of these health- and sanitation-related variables can explain the variation in country responses to COVID-19. It is worth noting that this article is silent regarding whether differences in responses across countries are due to differences in sanitation and health systems or differences in incomes across countries, since these variables are highly correlated.

Early in 2020, the general expectation was that the coronavirus pandemic's effects would be more severe in developing countries than in advanced economies, on both the public health and economic fronts. According to Goldberg and Reed (2020), preliminary evidence as of June 2020 supports a more optimistic assessment. According to their investigation, to date, most low- and middle-income countries have had a significantly lower death toll per capita than richer countries, a pattern they attribute primarily to younger populations and limited obesity. On the economic front, emerging market and developing economies have seen massive capital outflows and large price declines for certain commodities, especially oil and nonprecious metals; however, Goldberg and Reed (2020) suggest that these changes are in line with earlier commodity price shocks. They conclude that in the long run, the highest costs may be due to the indirect effects of virus containment policies on poverty, health, and education as well as to the effects of the accelerating deglobalization of emerging market and developing economies.

Finally, I look at whether economic variables that could affect the resources that countries have to navigate the impact of a substantial fall in economic activity could be responsible for the variation in responses. Macroeconomic variables could be changing the payoff function of the policymaker. Rich economies might have a different threshold for minimum consumption than poor countries; hence, they might be able to afford larger investment in health at the expense of the economy. I find that once differences in income and population density are taken into account, differences in the sizes of the financial and trading sectors can additionally explain variation in responses across countries. Demirguc-Kunt, Lokshin, and Torre (2020) provide an estimate of the economic impacts of the non-pharmaceutical interventions implemented by countries in Europe and Central Asia over the initial stages of the COVID-19 pandemic. Their results suggest that non-pharmaceutical interventions led to about a 10 percent decline in economic activity across the regions. On average, countries that implemented nonpharmaceutical interventions in the early stages of the pandemic appear to have had better short-term economic outcomes and lower cumulative mortality, compared with countries that imposed non-pharmaceutical interventions during the later stages of the pandemic. In part, this is because the interventions have been less stringent. Moreover, there is evidence that COVID-19 mortality at the peak of a local outbreak has been lower in countries that acted earlier.

The article is organized as follows. Section 2 reports the sources and the construction of the main variables used throughout the article. Section 3 presents the empirical analysis and main results. Section 4 concludes. 


\section{DATA}

This article puts together databases from several sources. Data on COVID-19 total cases and deaths are from Roser et al. (2020), who collect this information as posted by the European Center for Disease Prevention and Control. Data on "activity" are from Google's (2020) "COVID-19 Community Mobility Reports." I use changes in retail and recreation activity relative to January 2020 as the main measure of activity. This variable is highly correlated with other mobility measures in the dataset such as workplace mobility and transit station activity (see Figure A2 in the appendix). The relative fall in mobility accounts for the fall in activity overall, not necessarily just from measures imposed by local governments. Additionally, a fall in retail and recreation activity does not necessarily imply a fall in economic activity of the same degree, since many people continued working from home and attended on-line activities. Nevertheless, a substantial fall in activity relative to January 2020 indicates a significant change in the population's behavior during the early months of the pandemic.

I use Freedom House's "Freedom in the World 2020" global report on political rights and civil liberties and the freedom index therein to assess the degree of real-world rights and freedoms enjoyed by individuals within each country, which I call freedom. Given wide variation in government containment measures in response to COVID-19, the goal is to assess whether differences in the speeds of quarantine and lockdown measures can be explained by differences in the degree of freedom. I would expect to see that countries that have high levels of freedom would take significantly longer to engage their population into quarantines and lockdowns.

The variable Freedom comes from the Freedom House freedom index, which is constructed by analysts who use a broad range of sources, including news articles, academic analyses, reports from nongovernmental organizations, individual professional contacts, and on-theground research. The index is composed of a combination of points from political rights questions, including on the electoral process, political pluralism and participation, and the functioning of government, and from civil liberties questions, including on freedom of expression and beliefs, associational and organizational rights, rule of law and personal autonomy, and individual rights. $\underline{3}$

Data on macroeconomic variables such as gross domestic product (GDP) per capita, unemployment, public debt, health, water access and sanitation, and population variables are from World Development Indicators (WDI, 2020). My dataset includes 128 countries with the daily evolution of total cases, deaths, and mobility from February 15 to June 27, 2020. Macroeconomic, health, and freedom data are the most-recent annual data, so I only have one observation per country. In the appendix, see Table A9 for a list of all countries included in the sample, Table A1 for descriptive statistics of the main variables used, and Table A10 for short descriptions and sources of all the variables used.

\subsection{Lockdown}

I construct a measure of lockdown speed as the number of days before the country reduces its activity by 65 percent. Figure 2 shows how long it took for countries to reduce their activity 


\section{Gutkowski}

\section{Figure 2}

\section{Number of Country Lockdowns After 1, 100, and 500 Confirmed Cases}

A.

Number of countries

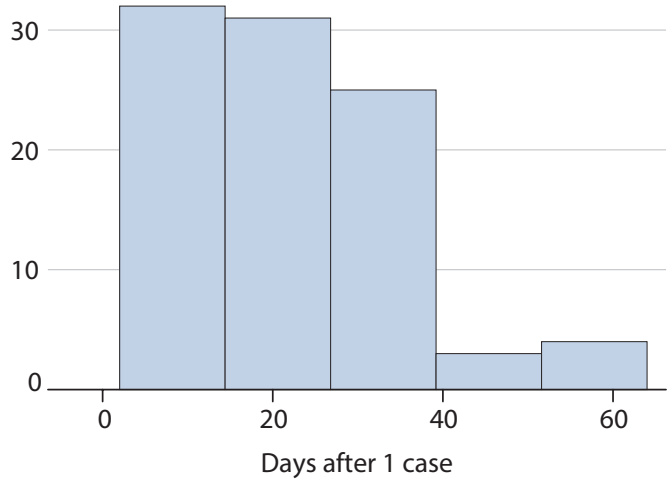

C.

Number of countries

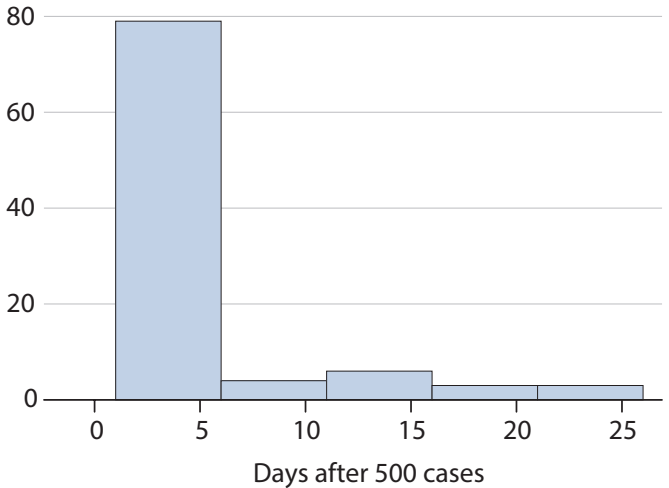

B.

Number of countries

80

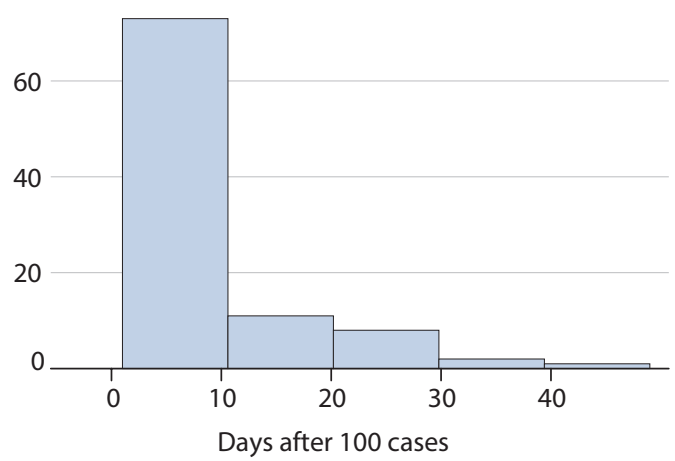

NOTE: A lockdown is defined as at least a 65 percent fall in activity relative to the baseline.

SOURCE: The lockdown measure is constructed using Google's (2020) "COVID-19 Community Mobility Reports."

to this level after the first confirmed case, 100 cases, and 500 cases. While most countries had substantially reduced their activity a few days after reaching 500 confirmed cases, there is more dispersion in their responses when the number of confirmed cases is lower. I study the correlation between lockdown speed (measured in days) and freedom in addition to several economic and health variables that could be related to vulnerability to COVID-19.

Various measures for government containment responses to the virus have been used in the literature. For example, Hale et al. (2020) construct a COVID-19 Government Response Stringency Index that is a composite measure of seven indicators related to school and workplace closings, international travel bans, restrictions on public events and gatherings, and stay-at-home requirements, among others. The lockdown measure used in this article is not directly related to government measures per se but is the likelihood of lockdown measures 


\section{Figure 3}

\section{Correlation of Lockdown Speed}

A.

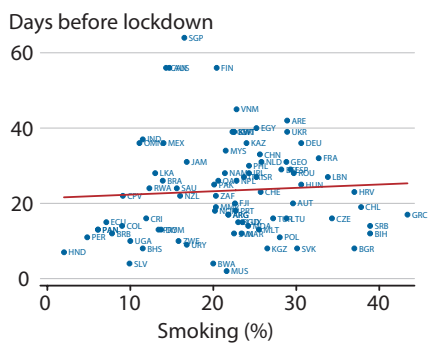

D.

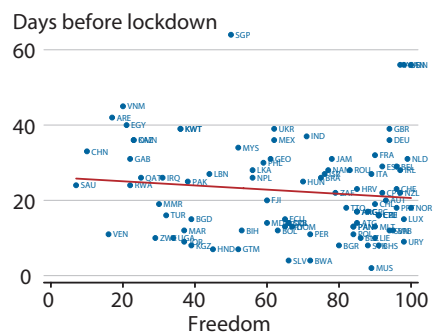

G.

Days before lockdown 60

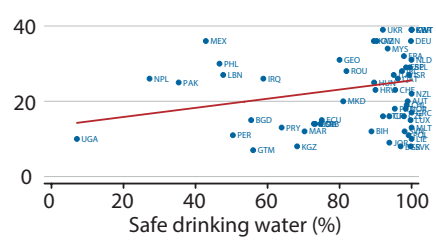

J.

Days before lockdown

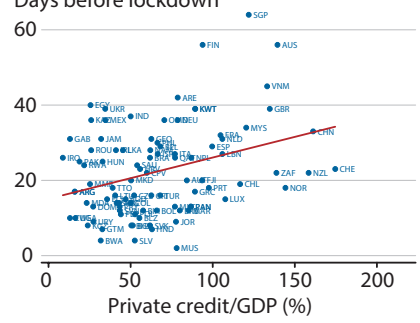

M.

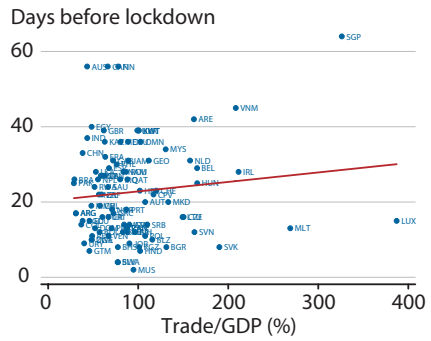

B.

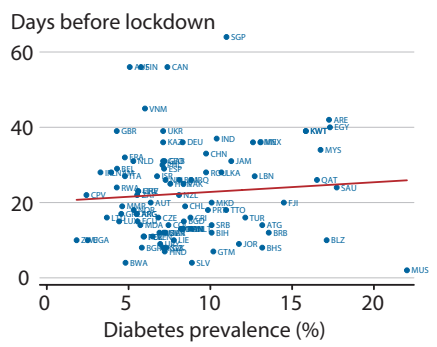

E.

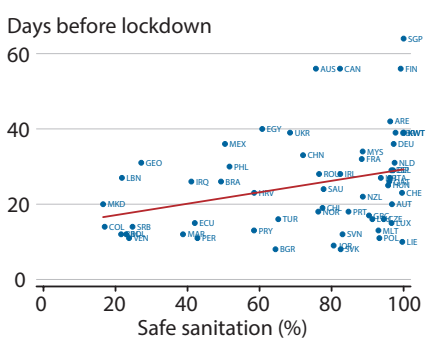

H.

Days before lockdown

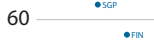

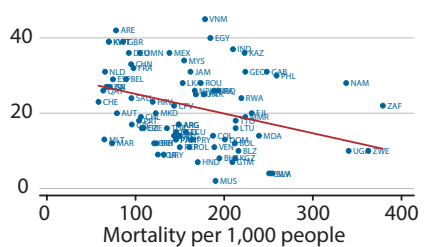

K.

Days before lockdown

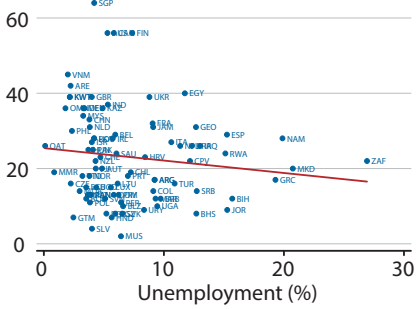

N.

Days before lockdown

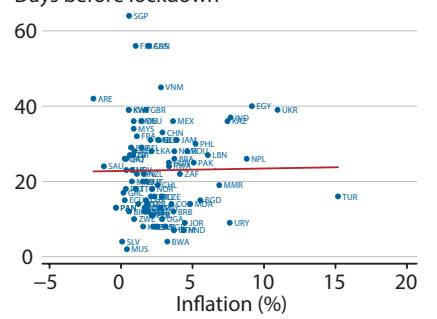

C.

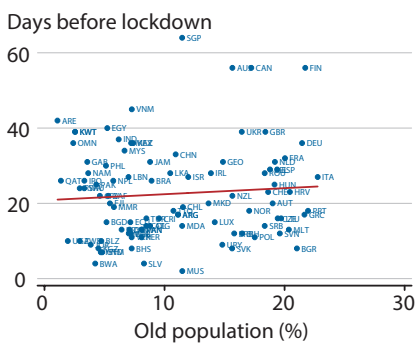

F.

Days before lockdown

60

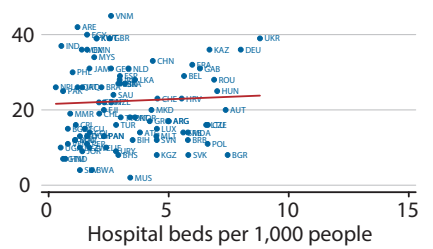

I.

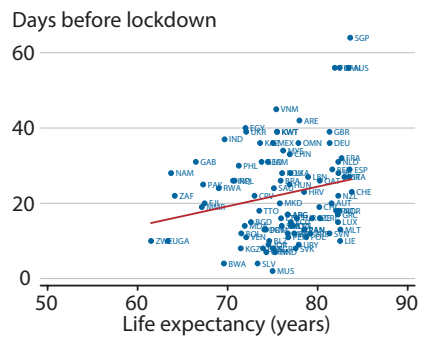

L.

Days before lockdown

60

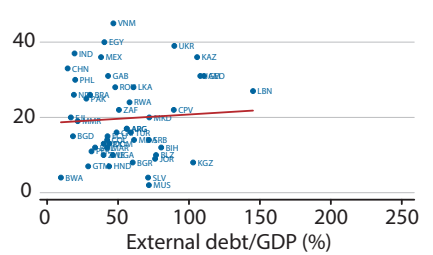

o.

Days before lockdown

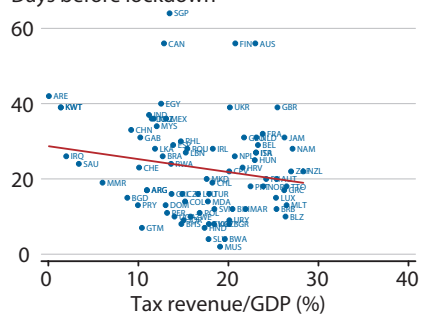

NOTE: Correlation between lockdown speed and health or economic vulnerability. $y$-axes: Days between first COVID-19 case and lockdown (65 percent fall in activity). $x$-axes: See Table A10 for descriptions of measurements. 
Table 1

Correlation Between Lockdown Speed and Health or Economic Vulnerability

\begin{tabular}{|c|c|c|c|}
\hline Life expectancy & Freedom & Political rights & Civil liberties \\
\hline $\begin{array}{l}1.003 * * * \\
(0.1690)\end{array}$ & $\begin{array}{r}0.065 \\
(0.0394)\end{array}$ & $\begin{array}{r}0.146 \\
(0.0907)\end{array}$ & $\begin{array}{r}0.112 \\
(0.0680)\end{array}$ \\
\hline Smoking & Old population & Population density & Diabetes prevalence \\
\hline $\begin{array}{r}0.127 \\
(0.1210)\end{array}$ & $\begin{array}{l}0.584^{* * *} \\
(0.1620)\end{array}$ & $\begin{array}{l}0.000887 \\
(0.00404)\end{array}$ & $\begin{array}{r}0.180 \\
(0.2520)\end{array}$ \\
\hline Safe drinking water & Safe sanitation & $\begin{array}{c}\text { Hospital beds } \\
\text { per } 1,000 \text { people }\end{array}$ & Mortality \\
\hline $\begin{array}{l}0.156^{* * *} \\
(0.0511)\end{array}$ & $\begin{array}{l}0.126^{* * *} \\
(0.0309)\end{array}$ & $\begin{array}{r}0.447 \\
(0.5080)\end{array}$ & $\begin{array}{r}-0.0593^{* * *} \\
(0.0125)\end{array}$ \\
\hline Trade/GDP & External debt/GDP & Unemployment & Private credit/GDP \\
\hline $\begin{array}{r}0.012 \\
(0.0179)\end{array}$ & $\begin{array}{r}-0.058 \\
(0.0338)\end{array}$ & $\begin{array}{r}-0.408^{* *} \\
(0.1870)\end{array}$ & $\begin{array}{l}0.122^{* * *} \\
(0.0219)\end{array}$ \\
\hline GDP per capita & $\begin{array}{c}\text { Financial sector } \\
\text { credit/GDP }\end{array}$ & Tax revenue/GDP & Public debt/GDP \\
\hline $\begin{array}{l}3.983^{* * *} \\
(0.6590)\end{array}$ & $\begin{array}{l}0.115^{* * *} \\
(0.0171)\end{array}$ & $\begin{array}{r}-0.179 \\
(0.1750)\end{array}$ & $\begin{array}{r}-0.005 \\
(0.0548)\end{array}$ \\
\hline
\end{tabular}

NOTE: Robust standard errors are in parentheses. ${ }^{* *} p<0.01,{ }^{* *} p<0.05,{ }^{*} p<0.10$. Lockdown speed is days between the first confirmed COVID-19 case and a 65 percent fall in activity.

enforcing changes in the population's behavior. Nevertheless, Figure A1 shows that lockdown speed based on this measurement is highly correlated with the speed or timing that would result from using the Hale et al. (2020) Stringency Index.

Figure 3 plots the main variables of interest-freedom, macroeconomic, and health conditions variables-against the measure of lockdown speed; Table 1 shows the significance of these correlations, taking into account that countries had different lockdown starting dates. Note that a significant positive correlation implies a significantly longer time until lockdown. For example, the significant positive correlation for life expectancy implies that countries with a higher life expectancy took significantly longer to lock down than countries with a lower life expectancy.

I find that countries that were more vulnerable to contagion achieved faster nonpharmaceutical measures to reduce the probability of the spread of the pandemic by locking down their economies earlier. In particular, countries with better access to safe sanitation and drinking water, higher life expectancy, and lower mortality rates responded more slowly to the pandemic. However, countries more vulnerable to the virus due to health conditions, such as large fractions of older adults, smokers, or diabetics in the population, did not respond

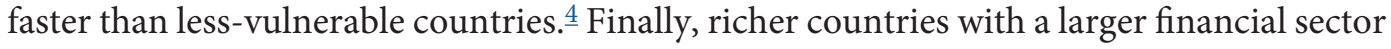
took longer to lock down their economies, while other macroeconomic conditions such as the tax-revenue-to-GDP ratio, public debt, and political rights and civil liberties were uncorrelated with the decision to lock down. 


\section{EMPIRICAL STRATEGY}

So far I have provided a description of lockdowns across countries. What could be driving the variation in country responses to COVID-19? At first sight, it seems that richer countries (in per capita terms) -with higher life expectancy and a large fraction of the population with access to safe drinking water and sanitation-took longer to respond. Can the degree of political rights and civil liberties explain differences in lockdown speeds across countries? Can the variation in economic conditions explain the differences? Or can the ease of contagion and the vulnerability of the population to the disease explain the differences?

A wide literature combining economic models with the SIR model of contagion used by public health specialists has highlighted the trade-off between reducing economic activity by reducing social interaction and reducing the rate of infections. At the heart of the standard SIR model, there is a matching function that mixes susceptible individuals (S) with infected individuals (I). Because private and public returns from social distancing differ due to externalities not taken into account by private agents, intervention could be desirable. The lack of political rights and civil liberties could reduce the externality problem. In other words, less individual liberty might imply more coordination and compliance, making the solution to the problem closer to the social optimum. The health status of the population measures the set of potentially susceptible individuals; thus, populations with a potentially better health status might be less likely to get infected from contact with individuals with the disease. Additionally, hospital capacity as well as macroeconomic variables can change the payoff function of the policymaker.

I find that freedom cannot explain differences in behavior across countries. Countries with a larger private-credit-to-GDP ratio took significantly longer to reduce their activity, probably because the cost of locking down the economy was higher. Additionally, countries with a larger trading sector were faster at implementing measures against COVID-19 contagion. Finally, countries more vulnerable to contagion were faster at implementing effective containment measures against COVID-19, while countries with populations more vulnerable to death from COVID-19 due to pre-existing characteristics do not seem to have behaved differently from less-vulnerable countries. However, once GDP per capita is taken into account, these differences in behavior to suppress contagion are no longer significant.

\subsection{Freedom, Political Rights, and Civil Liberties}

First, I test whether countries with higher levels of freedom took longer to lock down. I perform the following analysis:

$$
\text { Days }_{i}=\beta_{0}+\beta_{1} \text { Freedom }+\beta_{2} \mathbf{X}_{i}+\epsilon_{i} .
$$

The dependent variable is days between the day in which the first 100 cases were confirmed and the day in which the country had reached a large lockdown (activity fell 65 percent relative to the baseline in January 2020). The main explanatory variable to assess the degree of realworld rights and freedoms enjoyed by individuals within each country is Freedom. One could think that given the substantial polarity in the responses of the United States and China, civil 


\section{Gutkowski}

\section{Table 2}

Civil Freedom and Lockdown Timing

\begin{tabular}{|c|c|c|c|c|c|c|c|}
\hline & $\begin{array}{c}\text { (1) } \\
\text { L65_day1 }\end{array}$ & $\begin{array}{c}\text { (2) } \\
\text { L65_day100 }\end{array}$ & $\begin{array}{c}\text { (3) } \\
\text { L65_day500 }\end{array}$ & $\begin{array}{c}\text { (4) } \\
\text { L65_day100 }\end{array}$ & $\begin{array}{c}\text { (5) } \\
\text { L65_day100 }\end{array}$ & $\begin{array}{c}\text { (6) } \\
\text { L50_day100 }\end{array}$ & $\begin{array}{c}\text { (7) } \\
\text { L80_day100 }\end{array}$ \\
\hline Freedom & $\begin{array}{r}0.0174 \\
(0.0371)\end{array}$ & $\begin{array}{l}-0.0933 \\
(0.0606)\end{array}$ & $\begin{array}{l}-0.0103 \\
(0.0289)\end{array}$ & & & $\begin{array}{l}-0.0067 \\
(0.0259)\end{array}$ & $\begin{array}{l}-0.0098 \\
(0.0790)\end{array}$ \\
\hline Political rights & & & & $\begin{array}{l}-0.177 \\
(0.130)\end{array}$ & & & \\
\hline Civil liberties & & & & & $\begin{array}{l}-0.179 \\
(0.106)\end{array}$ & & \\
\hline GDP per capita & $\begin{array}{r}1.187 \\
(1.734)\end{array}$ & $\begin{array}{r}5.031^{* *} \\
(1.987)\end{array}$ & $\begin{array}{c}2.458^{*} \\
(1.310)\end{array}$ & $\begin{array}{r}4.741^{* *} \\
(1.901)\end{array}$ & $\begin{array}{r}5.213^{* *} \\
(2.005)\end{array}$ & $\begin{array}{r}3.386^{* * *} \\
(0.604)\end{array}$ & $\begin{array}{l}4.879^{*} \\
(2.747)\end{array}$ \\
\hline Population density & $\begin{array}{r}0.00135 \\
(0.00395)\end{array}$ & $\begin{array}{r}0.00229 \\
(0.00485)\end{array}$ & $\begin{array}{r}0.00059 \\
(0.00264)\end{array}$ & $\begin{array}{r}0.00230 \\
(0.00504)\end{array}$ & $\begin{array}{r}0.00230 \\
(0.00472)\end{array}$ & $\begin{array}{r}0.00146 \\
(0.00214)\end{array}$ & $\begin{array}{l}-0.00250 \\
(0.00612)\end{array}$ \\
\hline Constant & $\begin{array}{r}-5.09 \\
(14.84)\end{array}$ & $\begin{array}{r}-33.86^{* *} \\
(15.29)\end{array}$ & $\begin{array}{r}-18.65^{*} \\
(10.60)\end{array}$ & $\begin{array}{r}-32.63^{* *} \\
(14.90)\end{array}$ & $\begin{array}{r}-34.66^{* *} \\
(15.40)\end{array}$ & $\begin{array}{r}-23.90^{* * *} \\
(5.56)\end{array}$ & $\begin{array}{l}-31.37 \\
(24.03)\end{array}$ \\
\hline Observations & 92 & 92 & 92 & 92 & 92 & 113 & 60 \\
\hline$R^{2}$ & 0.521 & 0.625 & 0.621 & 0.617 & 0.631 & 0.924 & 0.891 \\
\hline
\end{tabular}

NOTE: Robust standard errors are in parentheses. ${ }^{* *} p<0.01,{ }^{* *} p<0.05,{ }^{*} p<0.10$. LXdayC:X percent fall in activity after the first C COVID-19 case(s) confirmed. These regressions include time fixed effects to account for differences across countries in the dates of the first confirmed COVID-19 case.

liberties could account for the differences in country responses to COVID-19. A positive and significant coefficient $\beta_{1}$ would imply that countries with a higher level of freedom took longer to enforce non-pharmaceutical measures to protect their population from the spread of the disease. $\mathbf{X}_{i}$ is a vector of control variables that includes the logarithm of GDP per capita and population density.

Table 2 shows the results for this analysis. $L X$ dayC stands for a lockdown that implied an $X$ percent fall in activity after the first $C$ confirmed case(s). After controlling for GDP per capita and population density, none of the variables related to levels of Freedom - the freedom index, political rights index, or civil liberties index-can explain differences in lockdown speeds. This finding is robust to using partial (50 percent) and extreme ( 80 percent) lockdown measures (Columns 6 and 7 of Table 2) as well as considering days until the first 500 confirmed cases (Column 3 of Table 2). $\frac{5}{}$ My results are in line with the findings of Hale et al. (2020) and Frey, Chen, and Presidente (2020). Additionally, these results are robust to controlling by region, clustering at the region level, and analyzing different combinations of lockdown intensity and confirmed cases. These results are also robust when I allow the model to be nonlinear; Table A3 in the appendix provides analysis under different scenarios to support this finding.

\subsection{Macroeconomic Variables}

Next, I test whether macroeconomic variables can explain the variation in responses across countries, specifically, the public debt-to-GDP ratio, the unemployment rate, openness 


\section{Table 3}

Macroeconomic Variables and Lockdown Timing

L65_day 100

\begin{tabular}{|c|c|c|c|c|c|c|}
\hline & \\
\hline & (1) & $(2)$ & (3) & (4) & (5) & (6) \\
\hline Trade/GDP & $\begin{array}{r}-0.0435^{*} \\
(0.0241)\end{array}$ & & & & & \\
\hline Public debt/GDP & & $\begin{array}{l}-0.0563 \\
(0.0713)\end{array}$ & & & & \\
\hline Unemployment & & & $\begin{array}{l}-0.242 \\
(0.209)\end{array}$ & & & \\
\hline External debt/GDP & & & & $\begin{array}{l}-0.0647 \\
(0.0530)\end{array}$ & & \\
\hline Financial sector credit/GDP & & & & & $\begin{array}{r}0.0755^{* * *} \\
(0.0236)\end{array}$ & \\
\hline Private credit/GDP & & & & & & $\begin{array}{r}0.0723^{* * *} \\
(0.0230)\end{array}$ \\
\hline GDP per capita & $\begin{array}{r}4.557^{* * *} \\
(1.483)\end{array}$ & $\begin{array}{c}5.401^{*} \\
(2.785)\end{array}$ & $\begin{array}{r}3.914^{* *} \\
(1.422)\end{array}$ & $\begin{array}{r}3.648 \\
(2.475)\end{array}$ & $\begin{array}{c}2.226^{*} \\
(1.139)\end{array}$ & $\begin{array}{r}2.610^{* * *} \\
(1.140)\end{array}$ \\
\hline Population density & $\begin{array}{r}0.00550 \\
(0.00434)\end{array}$ & $\begin{array}{r}0.00255 \\
(0.00965)\end{array}$ & $\begin{array}{r}0.00101 \\
(0.00567)\end{array}$ & $\begin{array}{r}0.00969^{* *} \\
(0.00462)\end{array}$ & $\begin{array}{r}0.00121 \\
(0.00424)\end{array}$ & $\begin{array}{r}0.00322 \\
(0.00474)\end{array}$ \\
\hline Constant & $\begin{array}{r}-32.26^{* *} \\
(12.49)\end{array}$ & $\begin{array}{l}-39.68 \\
(24.53)\end{array}$ & $\begin{array}{r}-27.63^{* *} \\
(12.79)\end{array}$ & $\begin{array}{l}-24.38 \\
(19.07)\end{array}$ & $\begin{array}{r}-20.41^{*} \\
(10.13)\end{array}$ & $\begin{array}{r}-22.79 * * \\
(10.50)\end{array}$ \\
\hline Observations & 91 & 28 & 86 & 48 & 91 & 91 \\
\hline$R^{2}$ & 0.641 & 0.828 & 0.642 & 0.793 & 0.662 & 0.633 \\
\hline
\end{tabular}

NOTE: Robust standard errors are in parentheses. ${ }^{* *} p<0.01,{ }^{* *} p<0.05,{ }^{*} p<0.10$. LXdayC:X percent fall in activity after the first $C$ cases confirmed. These regressions include time fixed effects to account for differences across countries in the dates of the first confirmed COVID-19 case.

to trade, or the size of the financial sector. Macroeconomic variables could be changing the payoff function of the policymaker. For example, one could think that countries more economically unstable would have taken longer to respond to COVID-19 due to the devastating economic consequences a lockdown could bring and their scarce resources to navigate the expected economic downturn.

Following a similar exercise as before,

$$
\text { Days }_{i}=\beta_{0}+\beta_{1} \text { MacroVar }+\beta_{2} \mathbf{X}_{i}+\epsilon_{i} \text {. }
$$

I regress the number of days it took each country after its first 100 confirmed cases to reach activity 65 percent lower than it had in January 2020. Table 3 shows the main results. Note that a positive and significant coefficient $\beta_{1}$ implies a significantly slower response to COVID-19.

I find that countries with a larger financial sector took significantly longer than other countries to reduce their activity. This is true using several measures of financial sector such as the private credit-to-GDP ratio, financial sector credit-to-GDP ratio, or private credit provided by banks-to-GDP ratio (see Tables A4 and A5 in the appendix). 


\section{Gutkowski}

Surprisingly, macroeconomic variables such as the unemployment rate, external debt to GDP, inflation, and tax revenue to GDP (among others) do not explain the variation in country responses to COVID-19. One would have expected that countries would be concerned about the economic consequences of lockdowns. What I observe is that countries with a larger financial sector took significantly longer to lock down their economies, probably due to the fears of repeating the previous large financial crisis. In addition, countries with a higher tradeto-GDP ratio reacted faster than countries with a lower degree of trade. Tables A4 and A5 in the appendix provide robustness analysis that takes into account regional fixed effects and different combinations of lockdown intensity and confirmed cases. These tables also include other macroeconomic variables not included in Table 3; however, the do not have any explanatory power for differences in country responses to COVID-19.

\subsection{Health and Sanitation Variables}

In this section, I perform a similar analysis as before but now look into the health vulnerability and sanitation variables. In the SIR model, infected people transmit the virus to susceptible people at a rate that depends on the nature of the virus and on the frequency of social interaction. Populations with a potentially better health status are less likely to get infected from contact with individuals with the disease or if infected might have a lower likelihood of death. I find that, surprisingly, countries more vulnerable to COVID-19 due to large fractions of older adults, smokers, and/or diabetics in the population did not respond differently from less-vulnerable countries. The analysis I conduct is the following:

$$
\text { Days }_{i}=\beta_{0}+\beta_{1} \text { HealthVar }+\beta_{2} \mathbf{X}_{i}+\epsilon_{i} \text {. }
$$

Results can be found in Table 4. Although contagion variables such as water sanitation, access to drinking water, and the mortality rate significantly correlate with lockdown speed, $\underline{6}$ once GDP per capita is taken into account, these variables lose explanatory power. It is worth mentioning that this analysis is silent about whether differences in the responses across countries are due to differences in sanitation and health systems or differences in income across countries, since these variables are highly correlated. Also, note that a negative coefficient on access to drinking water implies that countries with better access to drinking water took significantly fewer days to lock down their economies. Nevertheless, this significance is not robust to different measures of lockdown intensity. $\underline{?}$

If we allow the model to be nonlinear to better fit the data, mortality becomes statistically significant-with a negative coefficient. That is, countries with a higher mortality rate locked down their economies significantly faster (see Table A6). Note that while the significance of mortality is robust to different levels of lockdown intensity and confirmed cases, the significance of the coefficient on the smoking population is not.

Finally, it would be interesting to know if richer countries with a higher health care capacity or better hygiene system actually took longer to lock down their economies relative to rich countries with a lower-quality hygiene system. Thus, I allow the model to have an interaction term between the health variable and GDP per capita: 


\section{Table 4}

Health and Contagion Variables and Lockdown Timing

Days before large lockdown after 100 cases (L65_day100)

\begin{tabular}{|c|c|c|c|c|c|c|c|c|}
\hline & & & & & & & & \\
\hline & (1) & $(2)$ & (3) & (4) & (5) & (6) & (7) & (8) \\
\hline Smoking & $\begin{array}{r}0.0818 \\
(0.0713)\end{array}$ & & & & & & & \\
\hline Old population & & $\begin{array}{r}0.0741 \\
(0.2550)\end{array}$ & & & & & & \\
\hline Diabetes prevalence & & & $\begin{array}{r}0.0950 \\
(0.2910)\end{array}$ & & & & & \\
\hline Safe drinking water & & & & $\begin{array}{r}-0.0665^{*} \\
(0.0381)\end{array}$ & & & & \\
\hline Safe sanitation & & & & & $\begin{array}{r}0.0543 \\
(0.0492)\end{array}$ & & & \\
\hline $\begin{array}{l}\text { Hospital beds per } \\
1,000 \text { people }\end{array}$ & & & & & & $\begin{array}{l}-0.468 \\
(0.425)\end{array}$ & & \\
\hline Mortality & & & & & & & $\begin{array}{l}-0.0280 \\
(0.0186)\end{array}$ & \\
\hline Life expectancy & & & & & & & & $\begin{array}{r}0.433 \\
(0.457)\end{array}$ \\
\hline GDP per capita & $\begin{array}{r}4.195^{* *} \\
(1.565)\end{array}$ & $\begin{array}{r}3.626^{* *} \\
(1.430)\end{array}$ & $\begin{array}{r}3.545^{* *} \\
(1.478)\end{array}$ & $\begin{array}{r}4.503^{* * *} \\
(1.083)\end{array}$ & $\begin{array}{r}2.651 \\
(1.777)\end{array}$ & $\begin{array}{r}4.075^{* * *} \\
(1.451)\end{array}$ & $\begin{array}{r}2.902^{* *} \\
(1.131)\end{array}$ & $\begin{array}{l}2.469 * \\
(1.434)\end{array}$ \\
\hline Population density & $\begin{array}{r}0.00235 \\
(0.00588)\end{array}$ & $\begin{array}{r}0.00240 \\
(0.00554)\end{array}$ & $\begin{array}{r}0.00021 \\
(0.00686)\end{array}$ & $\begin{array}{r}0.00215 \\
(0.00696)\end{array}$ & $\begin{array}{r}-0.000679 \\
(0.00693)\end{array}$ & $\begin{array}{r}0.00245 \\
(0.00522)\end{array}$ & $\begin{array}{r}-0.000567 \\
(0.00557)\end{array}$ & $\begin{array}{r}0.00182 \\
(0.00552)\end{array}$ \\
\hline Constant & $\begin{array}{r}-33.91 * * \\
(13.96)\end{array}$ & $\begin{array}{r}-28.02^{* *} \\
(12.56)\end{array}$ & $\begin{array}{r}-26.64^{* *} \\
(14.54)\end{array}$ & $\begin{array}{r}-29.30 * * * \\
(10.15)\end{array}$ & $\begin{array}{l}-20.48 \\
(15.02)\end{array}$ & $\begin{array}{r}-29.91^{* *} \\
(12.86)\end{array}$ & $\begin{array}{l}-15.88 \\
(10.50)\end{array}$ & $\begin{array}{l}-49.32 \\
(29.02)\end{array}$ \\
\hline Observations & 83 & 93 & 93 & 58 & 56 & 91 & 82 & 93 \\
\hline$R^{2}$ & 0.626 & 0.594 & 0.518 & 0.832 & 0.827 & 0.621 & 0.558 & 0.607 \\
\hline
\end{tabular}

NOTE: Robust standard errors are in parentheses. ${ }^{* *} p<0.01,{ }^{* *} p<0.05,{ }^{*} p<0.10$. LXdayC: X percent fall in activity after the first $C$ cases confirmed. These regressions include time fixed effects to account for differences across countries in the dates of the first confirmed COVID-19 case.

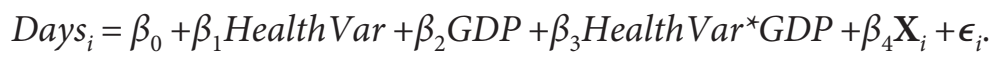

If $\beta_{3}$ were positive and significant, it would imply that richer countries with a better health care system took longer to lock down their economies, providing evidence to support differences in the payoff function of the policymaker that can be incorporated into the SIR model. Nevertheless, I do not find supportive evidence for this statement (Table 5), and this finding is robust to different levels of lockdown intensity and confirmed cases.

\section{CONCLUSION}

To sum up, this article combines several databases to study whether civil liberties and political rights influenced country responses to the pandemic. I find that different levels of 


\section{Gutkowski}

\section{Table 5}

Health and Contagion Variables Interaction with GDP

\begin{tabular}{|c|c|c|c|c|c|c|}
\hline & $\begin{array}{c}\text { (1) } \\
\text { L65_day100 }\end{array}$ & $\begin{array}{c}(2) \\
\text { L65_day100 }\end{array}$ & $\begin{array}{c}\text { (3) } \\
\text { L65_day100 }\end{array}$ & $\begin{array}{c}(4) \\
\text { L80_day1 }\end{array}$ & $\begin{array}{c}(5) \\
\text { L80_day1 }\end{array}$ & $\begin{array}{c}(6) \\
\text { L80_day1 }\end{array}$ \\
\hline Hospital beds per 1,000 people & $\begin{array}{l}-4.147 \\
(4.394)\end{array}$ & & & $\begin{array}{l}-10.030 \\
(15.880)\end{array}$ & & \\
\hline Hospital beds per 1,000 people $\times$ GDP & $\begin{array}{r}0.423 \\
(0.458)\end{array}$ & & & $\begin{array}{r}1.140 \\
(1.678)\end{array}$ & & \\
\hline Safe sanitation & & $\begin{array}{r}0.106 \\
(0.603)\end{array}$ & & & $\begin{array}{l}-1.432 \\
(2.497)\end{array}$ & \\
\hline Safe sanitation $x$ GDP & & $\begin{array}{l}-0.004 \\
(0.062)\end{array}$ & & & $\begin{array}{r}0.165 \\
(0.269)\end{array}$ & \\
\hline Safe drinking water & & & $\begin{array}{l}-0.412 \\
(0.562)\end{array}$ & & & $\begin{array}{l}-1.840 \\
(1.952)\end{array}$ \\
\hline Safe drinking water $\times$ GDP & & & $\begin{array}{r}0.040 \\
(0.063)\end{array}$ & & & $\begin{array}{r}0.204 \\
(0.240)\end{array}$ \\
\hline GDP per capita & $\begin{array}{r}2.500 \\
(1.787)\end{array}$ & $\begin{array}{r}2.199 \\
(4.147)\end{array}$ & $\begin{array}{r}1.009 \\
(5.395)\end{array}$ & $\begin{array}{l}-0.690 \\
(6.121)\end{array}$ & $\begin{array}{l}-10.330 \\
(18.950)\end{array}$ & $\begin{array}{l}-14.120 \\
(24.520)\end{array}$ \\
\hline Population density & $\begin{array}{l}-0.00041 \\
(0.00595)\end{array}$ & $\begin{array}{l}-0.00364 \\
(0.00712)\end{array}$ & $\begin{array}{r}0.00162 \\
(0.00686)\end{array}$ & $\begin{array}{r}0.00126 \\
(0.01040)\end{array}$ & $\begin{array}{l}-0.00086 \\
(0.01190)\end{array}$ & $\begin{array}{l}-0.00365 \\
(0.01380)\end{array}$ \\
\hline Constant & $\begin{array}{l}-15.69 \\
(15.57)\end{array}$ & $\begin{array}{l}-16.30 \\
(37.20)\end{array}$ & $\begin{array}{r}0.32 \\
(47.01)\end{array}$ & $\begin{array}{r}32.29 \\
(54.83)\end{array}$ & $\begin{array}{r}117.10 \\
(167.50)\end{array}$ & $\begin{array}{r}154.20 \\
(202.70)\end{array}$ \\
\hline Observations & 92 & 57 & 58 & 62 & 45 & 42 \\
\hline$R^{2}$ & 0.543 & 0.702 & 0.836 & 0.793 & 0.857 & 0.822 \\
\hline
\end{tabular}

NOTE: Robust standard errors are in parentheses. ${ }^{* *} p<0.01,{ }^{* *} p<0.05,{ }^{*} p<0.10 . \angle X$ dayC: $X$ percent fall in activity after the first $C$ case(s) confirmed. These regressions include time fixed effects to account for differences across countries in the dates of the first confirmed COVID-19 case.

political rights and civil liberties_-freedom—cannot explain differences in lockdown timing across countries. Vulnerability to fast contagion seems to have been at the heart of lockdown decisions. The health and contagion variables are highly correlated with a country's income level. Thus, once GDP per capita is taken into account, most health and contagion variables cannot further explain differences in country responses to the pandemic. Interestingly, macroeconomic variables that did affect lockdown were the sizes of a country's financial and trade sectors, even when taking into account income and population density differences across countries. This finding suggests that fears of another financial crisis might have played an important role in how countries decided to manage the COVID-19 pandemic. I perform several robustness checks and show that the main results are robust to controlling for differences in the timing of a country's first confirmed case (by controlling for time fixed effects); regional differences (by controlling for regional fixed effects); and different measures of lockdown intensity, that is, activity falling by 50 percent, 65 percent, or 80 percent. 


\section{APPENDIX: FIGURES AND TABLES}

\section{Figure A1}

\section{Correlation Between Mobility and Stringency Index}

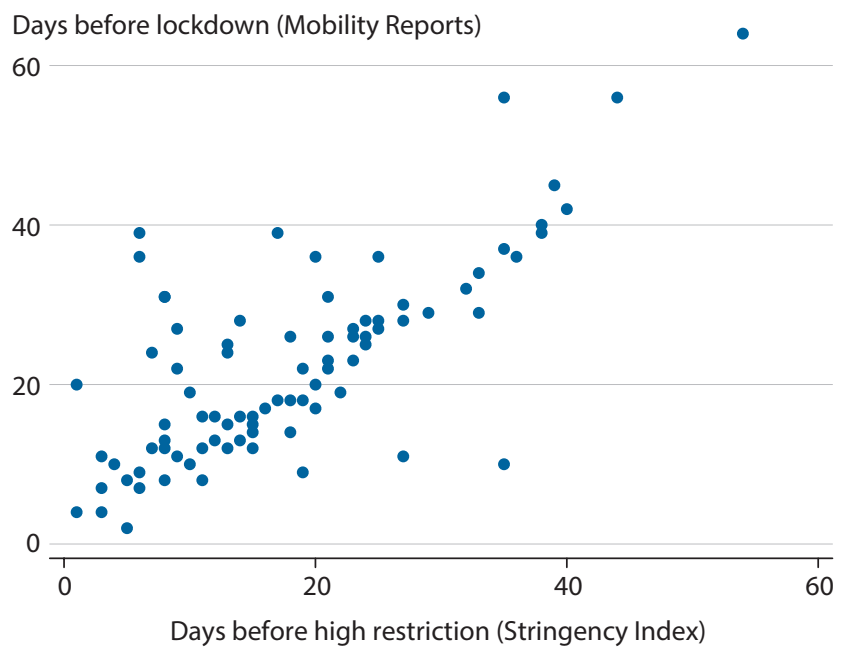

NOTE: $x$-axis: Days before a country reached a high level of restriction (65 percent fall in activity) using the Stringency Index. $y$-axis: Days to a 65 percent fall in activity (relative to January 2020) after the first confirmed COVID-19 case in a country. SOURCE: Activity is based on Google's (2020) "COVID-19 Community Mobility Reports." The Stringency Index is from Hale et al. (2020).

\section{Figure A2}

\section{Correlation Between Mobility Variables}

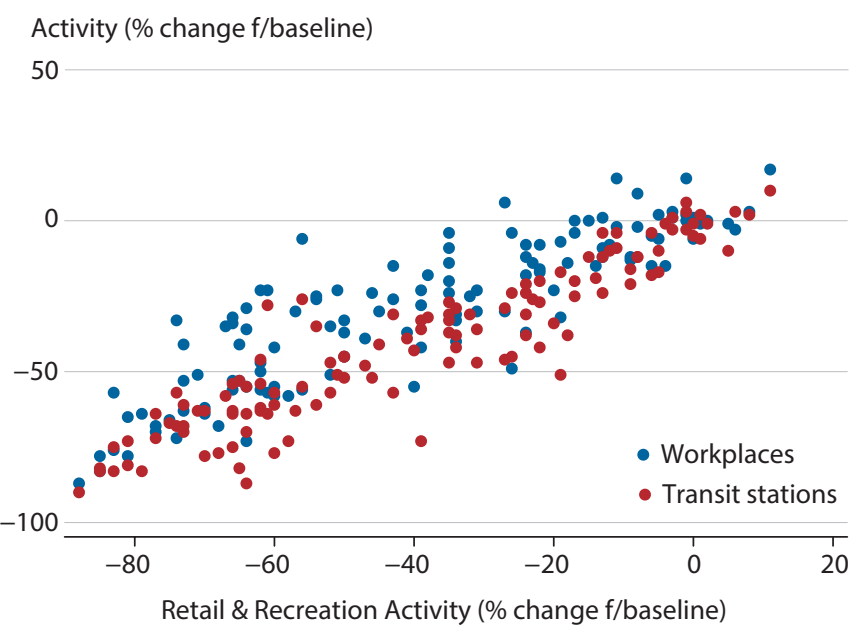

NOTE: Activity is measured as changes in mobility in retail and recreation, workspaces, and transit stations one day after the first 100 confirmed COVID-19 cases in a country relative to January 2020.

SOURCE: Activity is based on Google's (2020) "COVID-19 Community Mobility Reports." 


\section{Gutkowski}

\section{Table A1}

Descriptive Statistics: Explanatory Variables

\begin{tabular}{|c|c|c|c|c|c|c|c|c|}
\hline Variables & $\begin{array}{c}(1) \\
\text { Mean }\end{array}$ & $\begin{array}{l}(2) \\
S D\end{array}$ & $\begin{array}{l}\text { (3) } \\
\text { Min }\end{array}$ & $\begin{array}{l}\text { (4) } \\
\text { Max }\end{array}$ & $\begin{array}{l}(5) \\
p 5\end{array}$ & $\begin{array}{c}(6) \\
p 50\end{array}$ & $\begin{array}{c}(7) \\
p 95\end{array}$ & $\begin{array}{c}(8) \\
N\end{array}$ \\
\hline GDP per capita & 8.92 & 1.41 & 6.00 & 11.61 & 6.57 & 8.95 & 10.97 & 128 \\
\hline Population density & 155.80 & 212.50 & 1.98 & 1.45 & 6.68 & 83.48 & 528.00 & 127 \\
\hline Freedom & 62.69 & 28.11 & 7.00 & 100.00 & 16.00 & 66.00 & 98.00 & 127 \\
\hline Political rights & 25.02 & 12.59 & 0.00 & 40.00 & 2.00 & 27.00 & 40.00 & 127 \\
\hline Civil liberties & 37.67 & 15.80 & 6.00 & 60.00 & 12.00 & 38.00 & 58.00 & 127 \\
\hline External debt (\% of GDP) & 53.32 & 35.81 & 9.71 & 253.90 & 18.19 & 42.97 & 107.60 & 73 \\
\hline Domestic credit to private sector by banks (\% of GDP) & 56.94 & 37.10 & 8.70 & 174.60 & 13.02 & 50.21 & 133.10 & 124 \\
\hline Financial sector credit (\% of GDP) & 76.76 & 50.71 & 6.98 & 271.70 & 19.77 & 64.46 & 176.70 & 123 \\
\hline Private credit (\% of GDP) & 61.76 & 41.80 & 8.70 & 187.20 & 13.09 & 52.54 & 144.60 & 123 \\
\hline Public debt (\% of GDP) & 59.90 & 41.30 & 0.05 & 196.40 & 14.18 & 51.42 & 141.40 & 37 \\
\hline Tax revenue (\% of GDP) & 16.76 & 6.39 & 0.02 & 33.37 & 6.02 & 16.03 & 26.46 & 108 \\
\hline Trade (\% of GDP) & 90.11 & 54.52 & 27.54 & 387.10 & 36.18 & 77.24 & 165.50 & 124 \\
\hline Unemployment & 6.69 & 4.53 & 0.11 & 26.92 & 2.16 & 5.37 & 15.27 & 106 \\
\hline Smoking (\% of population) & 20.90 & 9.10 & 2.00 & 43.40 & 6.40 & 21.60 & 37.00 & 109 \\
\hline Old population (\% of population) & 9.89 & 6.75 & 1.09 & 27.58 & 2.39 & 7.27 & 21.02 & 128 \\
\hline Access to safe drinking water (\% of population) & 80.13 & 25.95 & 7.07 & 100.00 & 23.72 & 93.95 & 100.00 & 76 \\
\hline Access to safe sanitation (\% of population) & 71.16 & 28.43 & 9.61 & 100 & 18.71 & 82.41 & 99.65 & 73 \\
\hline Hospital beds per thousand people & 3.14 & 2.54 & 0.10 & 13.05 & 0.50 & 2.40 & 8.00 & 119 \\
\hline Life expectancy & 74.14 & 7.00 & 54.69 & 84.63 & 61.04 & 75.28 & 83.03 & 130 \\
\hline Mortality & 180.10 & 81.65 & 58.20 & 406.20 & 65.56 & 171.90 & 341.80 & 116 \\
\hline
\end{tabular}

\section{Table A2}

\section{Descriptive Statistics: Days to Lockdown}

\begin{tabular}{lrrrrrrrr} 
& Mean & SD & Min & Max & p5 & p50 & $p 95$ & $N$ \\
\hline Large lockdown: 500 cases (days) (L65_day500) & 3.65 & 5.80 & 1.00 & 26.00 & 1.00 & 1.00 & 19.00 & 95.00 \\
\hline Large lockdown: 100 cases (days) (L65_day100) & 7.05 & 8.96 & 1.00 & 49.00 & 1.00 & 3.00 & 25.00 & 95.00 \\
\hline Large lockdown: 1 case (days) (L65_day1) & 22.33 & 12.57 & 2.00 & 64.00 & 7.00 & 20.00 & 45.00 & 95.00 \\
\hline Partial lockdown: 100 cases (days) (L50_day100) & 6.86 & 12.67 & 1.00 & 105.00 & 1.00 & 1.00 & 32.00 & 118.00 \\
\hline Extreme lockdown: 100 cases (days) (L80_day100) & 13.53 & 14.54 & 1.00 & 69.00 & 1.00 & 8.50 & 41.00 & 64.00 \\
\hline Extreme lockdown: 500 cases (days) (L80_day500) & 7.98 & 11.41 & 1.00 & 62.00 & 1.00 & 1.50 & 29.00 & 64.00
\end{tabular}

NOTE: SD, standard deviation 


\section{Table A3}

Civil Freedom and Lockdown Timing

\begin{tabular}{|c|c|c|c|c|c|c|c|c|}
\hline & L65_day1 & L65_day 100 & L65_day500 & L65_day 100 & L65_day100 & L50_day 100 & L80_day 100 & L65_day 100 \\
\hline Freedom & $\begin{array}{r}0.0151 \\
(0.0888)\end{array}$ & $\begin{array}{l}-0.0577 \\
(0.0308)\end{array}$ & $\begin{array}{l}-0.0060 \\
(0.0213)\end{array}$ & & & $\begin{array}{l}-0.0155 \\
(0.0135)\end{array}$ & $\begin{array}{r}0.0640 \\
(0.0556)\end{array}$ & $\begin{array}{l}-0.2520 \\
(0.2940)\end{array}$ \\
\hline Political rights & & & & $\begin{array}{l}-0.0857 \\
(0.0747)\end{array}$ & & & & \\
\hline Civil liberties & & & & & $\begin{array}{r}-0.1280^{*} \\
(0.0534)\end{array}$ & & & \\
\hline Freedom 2 & & & & & & & & $\begin{array}{r}0.0014 \\
(0.0022)\end{array}$ \\
\hline GDP per capita & $\begin{array}{r}3.227 \\
(1.707)\end{array}$ & $\begin{array}{l}4.365^{* *} \\
(1.234)\end{array}$ & $\begin{array}{r}1.982 \\
(1.043)\end{array}$ & $\begin{array}{r}4.135^{* *} \\
(1.165)\end{array}$ & $\begin{array}{c}4.549^{* *} \\
(1.318)\end{array}$ & $\begin{array}{c}2.617^{* *} \\
(0.864)\end{array}$ & $\begin{array}{r}2.971 \\
(1.462)\end{array}$ & $\begin{array}{r}4.232^{* *} \\
(1.796)\end{array}$ \\
\hline Population density & $\begin{array}{l}-0.00151 \\
(0.00449)\end{array}$ & $\begin{array}{r}0.00171 \\
(0.00534)\end{array}$ & $\begin{array}{r}0.00085 \\
(0.00328)\end{array}$ & $\begin{array}{r}0.00152 \\
(0.00532)\end{array}$ & $\begin{array}{r}0.00184 \\
(0.00536)\end{array}$ & $\begin{array}{r}0.00048 \\
(0.00125)\end{array}$ & $\begin{array}{r}-0.00583^{* *} \\
(0.00135)\end{array}$ & $\begin{array}{r}0.00035 \\
(0.00547)\end{array}$ \\
\hline Constant & $\begin{array}{r}-1.28 \\
(24.98)\end{array}$ & $\begin{array}{l}-24.26 \\
(18.41)\end{array}$ & $\begin{array}{l}-10.30 \\
(13.10)\end{array}$ & $\begin{array}{l}-23.81 \\
(18.17)\end{array}$ & $\begin{array}{l}-24.65 \\
(18.61)\end{array}$ & $\begin{array}{l}-13.76 \\
(10.04)\end{array}$ & $\begin{array}{r}-16.42 \\
(9.96)\end{array}$ & $\begin{array}{l}-17.03 \\
(15.74)\end{array}$ \\
\hline Observations & 92 & 92 & 92 & 92 & 92 & 113 & 60 & 93 \\
\hline$R^{2}$ & 0.615 & 0.664 & 0.639 & 0.660 & 0.668 & 0.936 & 0.909 & 0.625 \\
\hline
\end{tabular}

NOTE: Robust standard errors are in parentheses. ${ }^{* *} p<0.01,{ }^{* *} p<0.05,{ }^{*} p<0.10$. LXdayC:X percent fall in activity after the first $C$ confirmed COVID-19 case(s). Freedom 2 is the squared term for Freedom. These regressions include time and region fixed effects to account for differences across countries in the dates of the first-reported COVID-19 case and regional differences. 


\section{Gutkowski}

\section{Table A4}

Macroeconomic Variables and Lockdown Timing

Days until partial lockdown date after 100 cases (L50_day100)

\begin{tabular}{|c|c|c|c|c|c|c|c|c|}
\hline Trade/GDP & $\begin{array}{l}-0.0204 \\
(0.0368)\end{array}$ & & & & & & & \\
\hline Public debt/GDP & & $\begin{array}{l}-0.0083 \\
(0.0334)\end{array}$ & & & & & & \\
\hline Tax revenue/GDP & & & $\begin{array}{l}-0.0770 \\
(0.0677)\end{array}$ & & & & & \\
\hline Unemployment & & & & $\begin{array}{l}-0.0545 \\
(0.1270)\end{array}$ & & & & \\
\hline External debt/GDP & & & & & $\begin{array}{r}-0.0603^{* * *} \\
(0.0116)\end{array}$ & & & \\
\hline Financial sector credit/GDP & & & & & & $\begin{array}{r}0.0662^{* *} \\
(0.0154)\end{array}$ & & \\
\hline Private credit/GDP & & & & & & & $\begin{array}{r}0.0594^{* * *} \\
(0.0124)\end{array}$ & \\
\hline Private credit (by banks)/GDP & & & & & & & & $\begin{array}{r}0.0622^{* * *} \\
(0.0130)\end{array}$ \\
\hline GDP per capita & $\begin{array}{c}2.845^{*} \\
(1.116)\end{array}$ & $\begin{array}{r}2.167 \\
(1.027)\end{array}$ & $\begin{array}{r}2.685^{* *} \\
(0.820)\end{array}$ & $\begin{array}{r}2.677^{* *} \\
(0.866)\end{array}$ & $\begin{array}{r}3.362^{* * *} \\
(0.306)\end{array}$ & $\begin{array}{r}1.014^{* * * *} \\
(0.131)\end{array}$ & $\begin{array}{c}1.467^{* *} \\
(0.377)\end{array}$ & $\begin{array}{r}1.466^{* *} \\
(0.581)\end{array}$ \\
\hline Population density & $\begin{array}{r}0.00117 \\
(0.00237)\end{array}$ & $\begin{array}{r}0.00879 \\
(0.02100)\end{array}$ & $\begin{array}{r}0.00015 \\
(0.00072)\end{array}$ & $\begin{array}{r}8.06 \mathrm{e}-06 \\
(0.00150)\end{array}$ & $\begin{array}{r}0.00027 \\
(0.00296)\end{array}$ & $\begin{array}{l}-0.00224 \\
(0.00113)\end{array}$ & $\begin{array}{l}-0.00092 \\
(0.00119)\end{array}$ & $\begin{array}{l}-0.00094 \\
(0.00147)\end{array}$ \\
\hline Constant & $\begin{array}{r}-16.74 \\
(10.700)\end{array}$ & $\begin{array}{l}-11.88 \\
(9.918)\end{array}$ & $\begin{array}{l}-14.16 \\
(9.734)\end{array}$ & $\begin{array}{r}-15.01 \\
(10.480)\end{array}$ & $\begin{array}{r}-17.25^{* * * *} \\
(3.351)\end{array}$ & $\begin{array}{l}-6.28^{*} \\
(2.502)\end{array}$ & $\begin{array}{r}-9.59 \\
(6.049)\end{array}$ & $\begin{array}{r}-9.41 \\
(7.400)\end{array}$ \\
\hline Observations & 111 & 35 & 98 & 101 & 63 & 109 & 109 & 111 \\
\hline$R^{2}$ & 0.942 & 0.947 & 0.941 & 0.942 & 0.921 & 0.956 & 0.950 & 0.947 \\
\hline
\end{tabular}




\section{Table A5}

Macroeconomic Variables and Lockdown Timing

Days until extreme lockdown date after 100 COVID-19 cases (L80_day100)

\begin{tabular}{|c|c|c|c|c|c|c|c|}
\hline Trade/GDP & $\begin{array}{r}-0.0823^{* * * *} \\
(0.0141)\end{array}$ & & & & & & \\
\hline Public debt/GDP & & $\begin{array}{l}0.0548 \\
(0.117)\end{array}$ & & & & & \\
\hline Unemployment & & & $\begin{array}{l}-0.200 \\
(0.242)\end{array}$ & & & & \\
\hline External debt/GDP & & & & $\begin{array}{l}-0.0690 \\
(0.0303)\end{array}$ & & & \\
\hline Financial sector credit/GDP & & & & & $\begin{array}{r}0.0550^{* *} \\
(0.0190)\end{array}$ & & \\
\hline Private credit/GDP & & & & & & $\begin{array}{r}0.0727^{* *} \\
(0.0212)\end{array}$ & \\
\hline Private credit (by banks)/GDP & & & & & & & $\begin{array}{r}0.0595^{* * *} \\
(0.0073)\end{array}$ \\
\hline GDP per capita & $\begin{array}{r}4.260^{* *} \\
(1.415)\end{array}$ & $\begin{array}{r}4.153^{* *} \\
(1.054)\end{array}$ & $\begin{array}{c}3.127^{* *} \\
(1.055)\end{array}$ & $\begin{array}{r}1.928 \\
(1.826)\end{array}$ & $\begin{array}{r}2.145^{* *} \\
(0.533)\end{array}$ & $\begin{array}{l}2.188^{*} \\
(0.901)\end{array}$ & $\begin{array}{l}2.340^{*} \\
(0.902)\end{array}$ \\
\hline Population density & $\begin{array}{l}-0.00146 \\
(0.00241)\end{array}$ & $\begin{array}{l}-0.00580 \\
(0.00968)\end{array}$ & $\begin{array}{r}-0.00712^{* * *} \\
(0.00149)\end{array}$ & $\begin{array}{r}0.00116 \\
(0.00230)\end{array}$ & $\begin{array}{r}-0.00725^{*} \\
(0.00272)\end{array}$ & $\begin{array}{l}-0.00548 \\
(0.00334)\end{array}$ & $\begin{array}{l}-0.00602 \\
(0.00368)\end{array}$ \\
\hline Constant & $\begin{array}{l}-18.11 \\
(12.75)\end{array}$ & $\begin{array}{r}-27.06^{* *} \\
(6.29)\end{array}$ & $\begin{array}{l}-10.63 \\
(11.87)\end{array}$ & $\begin{array}{r}-3.84 \\
(17.34)\end{array}$ & $\begin{array}{r}-10.42 \\
(5.70)\end{array}$ & $\begin{array}{r}-12.83 \\
(6.20)\end{array}$ & $\begin{array}{r}-10.92 \\
(8.33)\end{array}$ \\
\hline Observations & 62 & 20 & 59 & 27 & 62 & 62 & 62 \\
\hline$R^{2}$ & 0.939 & 0.959 & 0.906 & 0.988 & 0.911 & 0.913 & 0.908 \\
\hline \multicolumn{8}{|c|}{$\begin{array}{l}\text { NOTE: Robust standard errors are in parentheses. }{ }^{* *} p<0.01,{ }^{* *} p<0.05,{ }^{*} p<0.10 . \angle X d a y C: X \text { percent fall in activity after the first } C \text { confirmed } \\
\text { COVID- } 19 \text { cases. These regressions include time and region fixed effects to account for differences across countries in the dates of the first-reported } \\
\text { COVID-19 case and regional differences. }\end{array}$} \\
\hline
\end{tabular}




\section{Gutkowski}

\section{Table A6}

Nonlinear Specification for Health and Contagion Variables

Days before large lockdown after 100 COVID-19 cases (L65_day100)

\begin{tabular}{|c|c|c|c|c|c|}
\hline Smoking & $\begin{array}{r}0.613^{*} \\
(0.3450)\end{array}$ & & & & \\
\hline Smoking 2 & $\begin{array}{r}-0.011 * \\
(0.006)\end{array}$ & & & & \\
\hline Old population & & $\begin{array}{l}-0.661 \\
(1.240)\end{array}$ & & & \\
\hline Old population 2 & & $\begin{array}{r}0.029 \\
(0.0489)\end{array}$ & & & \\
\hline Mortality & & & $\begin{array}{r}-0.135^{* *} \\
(0.0617)\end{array}$ & & \\
\hline Mortality 2 & & & $\begin{array}{r}0.000250^{*} \\
(0.0001)\end{array}$ & & \\
\hline Life expectancy & & & & $\begin{array}{l}-3.807 \\
(5.347)\end{array}$ & \\
\hline Life expectancy 2 & & & & $\begin{array}{r}0.029 \\
(0.0374)\end{array}$ & \\
\hline Hospital beds per 1,000 people & & & & & $\begin{array}{r}-1.838 \\
(1.8070)\end{array}$ \\
\hline Hospital beds per 1,000 people 2 & & & & & $\begin{array}{r}0.209 \\
(0.1970)\end{array}$ \\
\hline GDP per capita & $\begin{array}{r}3.754^{* *} \\
(1.690)\end{array}$ & $\begin{array}{r}3.431^{* *} \\
(1.421)\end{array}$ & $\begin{array}{r}1.871 \\
(1.106)\end{array}$ & $\begin{array}{r}1.739 \\
(1.676)\end{array}$ & $\begin{array}{r}3.868^{* *} \\
(1.691)\end{array}$ \\
\hline Population density & $\begin{array}{r}-3.69 \mathrm{e}-05 \\
(0.00686)\end{array}$ & $\begin{array}{r}-8.68 \mathrm{e}-05 \\
(0.00589)\end{array}$ & $\begin{array}{l}-0.00417 \\
(0.00627)\end{array}$ & $\begin{array}{r}-0.000268 \\
(0.00686)\end{array}$ & $\begin{array}{r}4.40 \mathrm{e}-07 \\
(0.00621)\end{array}$ \\
\hline Constant & $\begin{array}{r}-34.25^{* *} \\
(14.12)\end{array}$ & $\begin{array}{l}-22.05 \\
(13.31)\end{array}$ & $\begin{array}{r}3.91 \\
(13.00)\end{array}$ & $\begin{array}{r}112.70 \\
(196.70)\end{array}$ & $\begin{array}{r}-25.90^{*} \\
(14.10)\end{array}$ \\
\hline Observations & 84 & 94 & 83 & 94 & 92 \\
\hline$R^{2}$ & 0.549 & 0.523 & 0.507 & 0.536 & 0.543 \\
\hline
\end{tabular}

NOTE: Robust standard errors are in parentheses. ${ }^{* *} p<0.01,{ }^{* *} p<0.05,{ }^{*} p<0.10$. LXdayC $: X$ percent fall in activity after the first $C$ confirmed COVID-19 cases. These regressions include time and region fixed effects to account for differences across countries in the dates of the first-reported COVID-19 case and regional differences. $X 2$ is the squared term for $X$. 


\section{Table A7}

Robustness: Health and Contagion Variables and Lockdown Timing

Days until extreme lockdown date after 500 cases (L65_day500)

\begin{tabular}{|c|c|c|c|c|c|c|c|}
\hline Smoking & $\begin{array}{l}-0.0060 \\
(0.0537)\end{array}$ & & & & & & \\
\hline Old population & & $\begin{array}{r}0.2350 \\
(0.2050)\end{array}$ & & & & & \\
\hline Safe drinking water & & & $\begin{array}{l}-0.0273 \\
(0.0463)\end{array}$ & & & & \\
\hline Safe sanitation & & & & $\begin{array}{r}0.0129 * * \\
(0.0031)\end{array}$ & & & \\
\hline Hospital beds per 1,000 people & & & & & $\begin{array}{l}-0.4360 \\
(0.2690)\end{array}$ & & \\
\hline Mortality & & & & & & $\begin{array}{l}-0.0103 \\
(0.0093)\end{array}$ & \\
\hline Life expectancy & & & & & & & $\begin{array}{c}0.4060^{*} \\
(0.1880)\end{array}$ \\
\hline GDP per capita & $\begin{array}{c}2.109 * \\
(0.951)\end{array}$ & $\begin{array}{r}1.729 \\
(1.121)\end{array}$ & $\begin{array}{r}3.028^{* *} \\
(0.993)\end{array}$ & $\begin{array}{c}2.697^{*} \\
(0.992)\end{array}$ & $\begin{array}{c}2.186^{*} \\
(0.854)\end{array}$ & $\begin{array}{r}1.587 \\
(1.246)\end{array}$ & $\begin{array}{l}0.887^{*} \\
(0.413)\end{array}$ \\
\hline Population density & $\begin{array}{r}0.00105 \\
(0.00349)\end{array}$ & $\begin{array}{r}0.00069 \\
(0.00336)\end{array}$ & $\begin{array}{r}0.00079 \\
(0.00112)\end{array}$ & $\begin{array}{r}0.00105 \\
(0.00138)\end{array}$ & $\begin{array}{r}0.00071 \\
(0.00310)\end{array}$ & $\begin{array}{l}-0.00179 \\
(0.00110)\end{array}$ & $\begin{array}{r}8.16 \mathrm{e}-05 \\
(0.00324)\end{array}$ \\
\hline Constant & $\begin{array}{l}-12.09 \\
(12.12)\end{array}$ & $\begin{array}{l}-11.68 \\
(11.38)\end{array}$ & $\begin{array}{r}-29.83^{* *} \\
(9.16)\end{array}$ & $\begin{array}{r}-21.76^{*} \\
(9.78)\end{array}$ & $\begin{array}{l}-12.10 \\
(10.70)\end{array}$ & $\begin{array}{l}-9.50 \\
(8.19)\end{array}$ & $\begin{array}{l}-32.86 \\
(21.09)\end{array}$ \\
\hline Observations & 83 & 93 & 58 & 56 & 91 & 82 & 93 \\
\hline$R^{2}$ & 0.644 & 0.648 & 0.846 & 0.846 & 0.671 & 0.547 & 0.661 \\
\hline
\end{tabular}

NOTE: Robust standard errors are in parentheses. ${ }^{* * *} p<0.01,{ }^{* *} p<0.05,{ }^{*} p<0.10$. LXdayC: $X$ percent fall in activity after the first $C$ confirmed COVID-19 cases. These regressions include time and region fixed effects to account for differences across countries in the dates of the first-reported COVID-19 case and regional differences. 


\section{Gutkowski}

\section{Table A8}

Robustness: Health and Contagion Variables and Lockdown Timing

Days until extreme lockdown date after 100 cases (L80_day100)

\begin{tabular}{|c|c|c|c|c|c|c|c|}
\hline Smoking & $\begin{array}{r}0.052 \\
(0.280)\end{array}$ & & & & & & \\
\hline Old population & & $\begin{array}{r}0.966^{* *} \\
(0.318)\end{array}$ & & & & & \\
\hline Safe drinking water & & & $\begin{array}{r}0.033 \\
(0.133)\end{array}$ & & & & \\
\hline Safe sanitation & & & & $\begin{array}{l}-0.115 \\
(0.057)\end{array}$ & & & \\
\hline Hospital beds per 1,000 people & & & & & $\begin{array}{r}1.632 \\
(0.893)\end{array}$ & & \\
\hline Mortality & & & & & & $\begin{array}{r}0.00950 \\
(0.00993)\end{array}$ & \\
\hline Life expectancy & & & & & & & $\begin{array}{r}0.371 \\
(0.869)\end{array}$ \\
\hline GDP per capita & $\begin{array}{r}2.799 \\
(1.779)\end{array}$ & $\begin{array}{r}1.291 \\
(0.632)\end{array}$ & $\begin{array}{r}5.473^{* * *} \\
(0.686)\end{array}$ & $\begin{array}{r}6.004^{* * * *} \\
(1.270)\end{array}$ & $\begin{array}{r}2.811^{* *} \\
(0.865)\end{array}$ & $\begin{array}{l}4.511^{*} \\
(1.885)\end{array}$ & $\begin{array}{r}2.022 \\
(1.567)\end{array}$ \\
\hline Population density & $\begin{array}{r}-0.00493^{* *} \\
(0.00127)\end{array}$ & $\begin{array}{l}-0.01010 \\
(0.00584)\end{array}$ & $\begin{array}{l}-0.00521 \\
(0.00321)\end{array}$ & $\begin{array}{l}-0.00707 \\
(0.00352)\end{array}$ & $\begin{array}{l}-0.00543 \\
(0.00343)\end{array}$ & $\begin{array}{l}-0.00739 \\
(0.00507)\end{array}$ & $\begin{array}{l}-0.00738 \\
(0.00574)\end{array}$ \\
\hline Constant & $\begin{array}{l}-11.24 \\
(14.33)\end{array}$ & $\begin{array}{l}-4.82 \\
(7.41)\end{array}$ & $\begin{array}{r}-35.47^{*} \\
(13.06)\end{array}$ & $\begin{array}{r}-33.02^{* *} \\
(9.69)\end{array}$ & $\begin{array}{l}-14.03 \\
(10.04)\end{array}$ & $\begin{array}{l}-25.59 \\
(15.79)\end{array}$ & $\begin{array}{l}-29.86 \\
(52.09)\end{array}$ \\
\hline Observations & 54 & 63 & 42 & 44 & 61 & 56 & 63 \\
\hline$R^{2}$ & 0.916 & 0.916 & 0.905 & 0.944 & 0.915 & 0.920 & 0.904 \\
\hline
\end{tabular}

NOTE: Robust standard errors are in parentheses. ${ }^{* *} p<0.01,{ }^{* *} p<0.05,{ }^{*} p<0.10$. LXday $C: X$ percent fall in activity after the first $C$ confirmed COVID-19 cases. These regressions include time and region fixed effects to account for differences across countries in the dates of the first-reported COVID-19 case and regional differences. 


\section{Table A9}

\section{List of Countries}

\begin{tabular}{|c|c|c|c|}
\hline Afghanistan & Ecuador & Libya & Romania \\
\hline Angola & Egypt & Lithuania & Russia \\
\hline Antigua and Barbuda & El Salvador & Luxembourg & Rwanda \\
\hline Argentina & Estonia & Macedonia & Saudi Arabia \\
\hline Aruba & Fiji & Malaysia & Senegal \\
\hline Australia & Finland & Mali & Serbia \\
\hline Austria & France & Malta & Singapore \\
\hline Bahamas & Gabon & Mauritius & Slovakia \\
\hline Bahrain & Georgia & Mexico & Slovenia \\
\hline Bangladesh & Germany & Moldova & South Africa \\
\hline Barbados & Ghana & Mongolia & South Korea \\
\hline Belarus & Greece & Morocco & Spain \\
\hline Belgium & Guatemala & Mozambique & Sri Lanka \\
\hline Belize & Guinea-Bissau & Myanmar & Sweden \\
\hline Benin & Haiti & Namibia & Switzerland \\
\hline Bolivia & Honduras & Nepal & Taiwan \\
\hline Bosnia and Herzegovina & Hungary & Netherlands & Tajikistan \\
\hline Botswana & India & New Zealand & Tanzania \\
\hline Brazil & Indonesia & Nicaragua & Thailand \\
\hline Bulgaria & Iraq & Niger & Togo \\
\hline Burkina Faso & Ireland & Nigeria & Trinidad and Tobago \\
\hline Cambodia & Israel & Norway & Turkey \\
\hline Cameroon & Italy & Oman & Uganda \\
\hline Canada & Jamaica & Pakistan & Ukraine \\
\hline Cape Verde & Japan & Panama & United Arab Emirates \\
\hline Chile & Jordan & Papua New Guinea & United Kingdom \\
\hline China & Kazakhstan & Paraguay & United States \\
\hline Colombia & Kenya & Peru & Uruguay \\
\hline Costa Rica & Kuwait & Philippines & Venezuela \\
\hline Cote d'Ivoire & Kyrgyzstan & Poland & Vietnam \\
\hline Croatia & Laos & Portugal & Yemen \\
\hline Czech Republic & Latvia & Puerto Rico & Zambia \\
\hline Denmark & Lebanon & Qatar & Zimbabwe \\
\hline
\end{tabular}




\section{Gutkowski}

\section{Table A10}

Robustness: Health and Contagion Variables and Lockdown Timing

\begin{tabular}{|c|c|c|}
\hline Variable & Short description & Source \\
\hline GDP per capita & GDP per capita (logs) & WDI (2020) \\
\hline Trade/GDP & Trade (\% of GDP) & WDI (2020) \\
\hline External debt/GDP & External debt stocks (\% of GDP) & WDI (2020) \\
\hline Unemployment & Unemployment, total (\% of total labor force) & WDI (2020) \\
\hline Private credit/GDP & Domestic credit to private sector (\% of GDP) & WDI (2020) \\
\hline Public debt/GDP & Central government debt, total (\% of GDP) & WDI (2020) \\
\hline Banks private credit/GDP & Domestic credit to private sector by banks (\% of GDP) & WDI (2020) \\
\hline Financial sect. credit/GDP & Domestic credit provided by financial sector (\% of GDP) & WDI (2020) \\
\hline Tax revenue/GDP & Tax revenue (\% of GDP) & Freedom House (2020) \\
\hline Inflation & Inflation, consumer prices (annual \%) & Freedom House (2020) \\
\hline Political rights & Political rights category score (40 points) & Freedom House (2020) \\
\hline Civil liberties & Civil liberties category score (60 points) & WDI (2020) \\
\hline Freedom & $\begin{array}{l}\text { Aggregate score for political rights and civil liberties categories } \\
\text { (100 points) }\end{array}$ & WDI (2020) \\
\hline Smoking & Smoking prevalence, total, ages $15+$ & WDI (2020) \\
\hline Old population & Population ages 65 and above (\% of total) & WDI (2020) \\
\hline Population density & Population density (people per sq. km of land area) & WDI (2020) \\
\hline Diabetes prevalence & $\begin{array}{l}\text { Diabetes prevalence ( type } 1 \text { or } 2 \text { diabetes ) (\% of population } \\
\text { ages } 20 \text { to 79) }\end{array}$ & WDI (2020) \\
\hline Safe drinking water & $\begin{array}{l}\text { People using safely managed drinking water services (\% of } \\
\text { population) }\end{array}$ & WDI (2020) \\
\hline Safe sanitation & $\begin{array}{l}\text { People using safely managed sanitation services (\% of } \\
\text { population) }\end{array}$ & WDI (2020) \\
\hline Hospital beds per 1,000 people & $\begin{array}{l}\text { Hospital beds in public, private, general, and specialized } \\
\text { hospitals and rehabilitation centers }\end{array}$ & WDI (2020) \\
\hline Mortality & Mortality rate, adult males (per 1,000) & WDI (2020) \\
\hline Life expectancy & Life expectancy at birth, total (years) & WDI (2020) \\
\hline Total cases & Total confirmed cases & \\
\hline L65_day 100 & $\begin{array}{l}\text { Days before large lockdown ( } 65 \% \text { fall in activity) since first } 100 \\
\text { confirmed COVID-19 cases }\end{array}$ & Roser et al. (2020) \\
\hline L50_day 100 & $\begin{array}{l}\text { Days before partial lockdown ( } 50 \% \text { fall in activity) since first } 100 \\
\text { confirmed COVID- } 19 \text { cases }\end{array}$ & Calculated using Google (2020) \\
\hline L80_day 100 & $\begin{array}{l}\text { Days before extreme lockdown ( } 80 \% \text { fall in activity) since first } \\
100 \text { confirmed COVID-19 cases }\end{array}$ & Calculated using Google (2020) \\
\hline LXdayC & $\begin{array}{l}\text { Days before } X \text { lockdown ( } X \% \text { fall in activity) since first } C \\
\text { confirmed COVID-19 case(s) }\end{array}$ & Calculated using Google (2020) \\
\hline
\end{tabular}




\section{NOTES}

1 Atkeson (2020) provides a good summary of this framework. The "R" of SIR is for recovered individuals, who are no longer contagious.

$\underline{2}$ Many counties within California had issued a "shelter in place" order a few days before.

$\underline{3}$ See https://freedomhouse.org/reports/freedom-world/freedom-world-research-methodology for details and methodology used by Freedom House.

4 Moreover, these results show that the opposite is true: Countries with a higher fraction of older adults took significantly longer to lock down.

5 Many countries have never reached an extreme quarantine, thus there are fewer observations for the extremelockdown scenario.

$\underline{6}$ This correlation is consistent with the fact that populations with a lower-quality hygiene system might have a higher rate of contagion

$\underline{7}$ Robustness exercises can be found in Tables A7 and A8.

\section{REFERENCES}

Atkeson, Andrew. "What Will Be the Economic Impact of Covid-19 in the US? Rough Estimates of Disease Scenarios." NBER Working Paper 26867, National Bureau of Economic Research, 2020; https://doi.org/10.3386/w26867.

Bosancianu, Manuel; Yi Dionne, Kim; Hilbig, Hanno; Humphreys, Macartan; Sampada, KC; Lieber, Nils and Scacco, Alexandra. "Social and Political Correlates of COVID-19." Manuscript, 2020; https://doi.org/10.31235/osf.io/ub3zd.

Cronert, Axel. "Democracy, State Capacity, and COVID-19 Related School Closures." APSA Preprints, 2020; https://doi.org/10.33774/apsa-2020-jf671-v3.

Demirguc-Kunt, Asli; Lokshin, Michael and Torre, Iván. "The Sooner, the Better: The Early Economic Impact of NonPharmaceutical Interventions During the COVID-19 Pandemic." Policy Research Working Paper 9257, World Bank, 2020; https://doi.org/10.1596/1813-9450-9257.

Farboodi, Maryam; Jarosch, Gregor and Shimer, Robert. "Internal and External Effects of Social Distancing in a Pandemic." NBER Working Paper 27059, National Bureau of Economic Research, 2020; https://doi.org/10.3386/w27059.

Freedom House. Freedom Scores. 2020; https://freedomhouse.org/countries/freedom-world/scores.

Frey, Carl Benedikt; Chen, Chinchih and Presidente, Giorgio. "Democracy, Culture, and Contagion: Political Regimes and Countries Responsiveness to COVID-19." Covid Economics, May 2020, 18, pp. 1-20.

Goldberg, Pinelopi K. and Reed, Tristan. "The Effects of the Coronavirus Pandemic In Emerging Market and Developing Economies: An Optimistic Preliminary Account." Brookings Papers on Economic Activity Conference, BPEA Conference Draft, Summer 2020.

Google. “COVID-19 Community PMobility Reports." 2020.

Hale, Thomas; Petherick, Anna; Phillips, Toby and Webster, Samuel. "Variation In Government Responses to COVID-19." Working Paper 31, Blavatnik School of Government, 2020.

Jones, Callum J.; Philippon, Thomas and Venkateswaran, Venky. “Optimal Mitigation Policies in a Pandemic: Social Distancing and Working from Home." NBER Working Paper 26984, National Bureau of Economic Research, 2020; https://doi.org/10.3386/w26984.

Roser, Max; Ritchie, Hannah; Ortiz-Ospina, Esteban and Hasell, Joe. "Coronavirus Pandemic (COVID-19)." Our World in Data, 2020; https://ourworldindata.org/coronavirus.

World Bank. World Development Indicators Database. 2020. 
